\title{
Un obispado para Veracruz, 1799-1846 Del honor de la ciudad a la lealtad al Estado ${ }^{1}$
}

\author{
David Carbajal \\ Universidad Veracruzana
}

Entre 1789 y 1846 las autoridades de Veracruz promovieron la creación de un Obispado con los límites de la jurisdicción a su cargo. Aunque la historiografía reciente ha destacado la continuidad existente entre el regalismo borbónico y el primer liberalismo mexicano, el análisis de los argumentos presentados por los munícipes y congresistas porteños, sugiere cambios tanto en el contexto institucional como en los principios en que se fundaban. Hasta 1821, se aludía a los privilegios propios de la ciudad más antigua del reino; durante la primera república federal, se insistió en defender el honor de la soberanía, postura que se radicaliza hacia 1833, cuando el Congreso veracruzano decretó, sin éxito, la creación de la nueva diócesis. El obispado fue creado en 1844, el gobierno del Departamento de Veracruz repitió sus solicitudes, con argumentos que muestran cierta continuidad con los del primer federalismo, a pesar del cambio al régimen centralista.

PALABRAS CLAVE: Veracruz, Iglesia, regalismo, liberalismo.

Between 1789 and 1846 the authorities of Veracruz promoted the creation of a Bishopric with with the limits of the jurisdiction to their charge. Although the recent historiography has noticeable the existing continuity between the regalismo Bourbon and the first Mexican liberalism, the analysis of the arguments presented by the municipes and congresspersons of Veracruz, suggests changes in the institutional context as in the principles in which they were founded. Until 1821, it was alluded to the own privileges of the oldest city of the kingdom; during the first federal republic, insisted on defending the honor of the sovereignty, position that is radicalized toward 1833, when the Congress decreed, without success, the creation of new diocese. The bishopric was created in 1844, the government of the Department of Veracruz repeated their requests, with arguments that show certain continuity with the of the first federalism, in spite of the change to the centralist regime.

KEYwords: Veracruz, Church, regalism, liberalism.

Entre 1789 y 1846 las autoridades de Veracruz promovieron al menos en seis ocasiones la creación de un obispado con los límites, primero de su provincia y luego del estado del mismo nombre. Aunque el tiempo transcurrido entre la primera y la última de dichas solicitudes haya sido relativamente corto, existe entre ellas la enorme distancia que separa a la

1 El autor agradece al dictaminador anónimo del Anuario de Estudios Americanos y al Dr. Stéphanne Michonneau por sus amables sugerencias, que han contribuido a mejorar este texto. 
Monarquía Católica Hispánica del Estado Nacional en construcción que las enmarcaron respectivamente. La historiografía mexicana de las últimas décadas ha resaltado la continuidad existente entre la política eclesiástica de los reyes de la Casa de Borbón y los primeros gobiernos independientes, ${ }^{2}$ girando ésta en torno al tema del patronato que los soberanos ejercieron sobre la Iglesia, y que les permitía, fundamentalmente, participar en la provisión de beneficios y en la división y erección de nuevas diócesis. Diversos autores han apuntado la importancia ideológica que tuvo, hasta bien entrado el siglo XIX, el regalismo característico de la política de reformas aplicada por los borbones, justificadas por derechos inherentes a la soberanía. Sin embargo, el contexto institucional y los motivos alegados en justificación para la creación o no del obispado de Veracruz marcan con claridad cambios importantes entre una y otra época, a pesar de que los actores y sus prácticas, más bien tradicionales, ciertamente se hayan modificado poco.

Hasta ahora la historiografía veracruzana ha destacado únicamente el tema de las rivalidades entre las urbes de la provincia, que se disputaron la sede episcopal; sin negar la importancia de ese debate, en este artículo centraremos nuestra atención en los argumentos de la ciudad de Veracruz y de la mitra y Cabildo Catedral de Puebla de los Ángeles, por ser particularmente representativos para nuestros fines. Mas antes de entrar en materia, consideraremos el contexto en que se inscriben cada uno de los sucesivos intentos en pro de obtener el obispado para Veracruz.

\section{La Monarquía Católica y el Real Patronato}

Conviene comenzar con una breve explicación de las facultades de la moarquía en el tema de la erección y división de obispados. Para ello debemos remontarnos hasta 1508, cuando el rey Fernando el Católico, como regente de Castilla y León por su hija la reina Juana, obtuvo del Papa Julio II la bula Universalis Ecclesiae, la cual concedió a los reyes castellanos, res-

2 Una línea de interpretación que empieza a esbozarse en la conclusión de Farriss, Nancy: Clero y Corona en el México colonial. La crisis del privilegio eclesiástico, Fondo de Cultura Económica, México, 1995, pág. 233, cuando indica las pocas diferencias entre el programa de reforma eclesiástica de Carlos III y la reforma de los liberales de mediados del siglo XIX, y que ha tenido particular importancia en los trabajos posteriores sobre las relaciones Iglesia-Estado durante los primeros años de la independencia, por ejemplo: Staples, Anne: La Iglesia en la primera república federal mexicana (1824-1835), Secretaría de Educación Pública, México, 167 págs.; Pérez Memen, Fernando: El Episcopado mexicano y la independencia de México, Jus, México, 380 págs. y Ferrer Muñoz, Manuel: La formación de un Estado nacional en México. El Imperio y la República Federal, 1821-1835, Instituto de Investigaciones Jurídicas - Universidad Nacional Autónoma de México, México, 379 págs. 
pecto de las iglesias de Indias: "Que nadie las pueda construir, edificar, ni erigir sin su expreso consentimiento...". ${ }^{3}$ Esta misma bula otorgó a los reyes el patronato sobre las mismas iglesias. Según explicaba el propio rescripto pontificio, el patronato consistía en el derecho de presentación de todos los arzobispos, obispos, prebendados y beneficiados; sin embargo, durante los tres siglos siguientes, la Monarquía hizo una interpretación bastante más amplia de los derechos adquiridos, remitiéndolos, no tan sólo a la bula de 1508, sino principalmente a las bulas otorgadas por el Papa Alejandro VI en 1493, célebres por conceder a los Reyes Católicos el dominio sobre las entonces recién descubiertas Indias Occidentales.

En el marco de esa interpretación amplia del Patronato Regio, la Monarquía se ocupaba también de autorizar la división de las iglesias diocesanas ya creadas. Aunque nunca hubo una concesión pontificia al respecto, ni los monarcas emitieron una real cédula que aclarase el punto de manera general, en la práctica las divisiones se hacían por la sede apostólica a petición de los reyes. Los criterios que normaban las divisiones debían ser "utilidad, necesidad y consentimiento de los obispos interesados", ${ }^{4}$ según lo declaraba una autoridad como Solórzano Pereira. Fue, pues, por autorización y petición regia al Papa que, entre 1519 y 1620, se crearon en el reino de la Nueva España una arquidiócesis, la de México, y seis diócesis sufragáneas: Tlaxcala (trasladada a Puebla), Antequera de Oaxaca, Valladolid de Michoacán, Yucatán, Guadalajara y Durango. Bajo el reinado de Carlos III se crearon dos diócesis más, Linares y Sonora, que completaron la división eclesiástica que se mantendría hasta bien entrado el siglo XIX.

A pesar del patronato y del regalismo característico de la monarquía borbónica, las iglesias de Indias no constituyeron un instrumento dócil a la voluntad de la Corona, ni el clero se convirtió en un brazo de la burocracia. Para comprender esta aparente paradoja conviene insistir aquí en la trascendencia de la Iglesia en el marco de la Monarquía Católica. La historiografía reciente sobre la "política" y el "Estado" en el Antiguo Régimen reconoce que en este orden político era impensable la existencia del "poder" en el sentido contemporáneo del término, por tanto no era tampoco posible una autoridad absoluta que actuase o pretendiese actuar efectivamente sobre toda la sociedad como sucede con los poderes públicos actuales. Antes bien, toda actitud autoritaria se concebía, negativamente desde luego, como "despotismo". En cambio, el sistema político funcionaba sobre la base de jurisdiccio-

3 Solórzano Pereira, Juan: Política Indiana, Libro IV, Capítulo II, n. 9.

4 Solórzano Pereira, Juan: Política Indiana, Libro IV, Capítulo V, n. 8. 
nes, frecuentemente superpuestas y en constante proceso de definición, que además justificaban sus procedimientos recurriendo a leyes, "autoridades", costumbres, privilegios y un amplio cuerpo de jurisprudencia acumulado a lo largo de los siglos. En la cúspide de este orden existía no el poder absoluto de una potestad pública entonces inexistente, sino una "diarquía jurisdiccional" - por emplear el término de Bartolomé Clavero- en que tanto la Corona como la propia Iglesia se pretendían y actuaban como soberanas. ${ }^{5}$

En el imaginario de esta Monarquía, confesionalmente católica, ambas jurisdicciones, las "dos potestades", debían colaborar en armonía para alcanzar el fin último del cuerpo político en su conjunto: su salvación eterna. ${ }^{6}$ Mas la "diarquía jurisdiccional" aseguraba a los eclesiásticos una posición privilegiada, y en ocasiones incluso una influencia mayor sobre la sociedad que la de las autoridades seculares.?

Ciertamente la Corona emprendió reformas fundamentadas en el regalismo, e incluso hubo intentos de socializarlo que se sirvieron del propio clero secular, ${ }^{8}$ pero los resultados fueron más bien escasos por su mode-

5 Síntesis muy apretada de la exposición de Clavero, Bartolomé: "El cambio político a examen clásico: De la diarquía jurisdiccional a la monocracia constitucional”, en Bernal, Antonio Miguel . (comps.): Antiguo Régimen y Liberalismo. Homenaje a Miguel Artola, Vol. I, Visiones generales, Alianza Editorial/Ediciones de la Universidad Autónoma de Madrid, Madrid, 1994, págs. 129-131.

6 Sobre el imaginario de las dos potestades, véase: Cañeque, Alejandro: "Cultura vicerregia y Estado colonial. Una aproximación crítica al estudio de la historia política de la Nueva España", Historia Mexicana, Vol. LI, Núm. 1, México, 2001, págs. 20-24.

7 Véase una síntesis del caso novohispano en Mazín, Óscar: "El trono y el altar, ejes rectores de la vida novohispana, hasta su crisis en la diócesis de Michoacán”, Historias, no. 39, México, octubre 1997-marzo 1998, págs. 27-37.

8 Lempérière, Annick: "La recepción negativa de una gran idea: El absolutismo en Nueva España en la segunda mitad del siglo XVIII", en Quijada, Mónica y Jesús Bustamante (eds.): Élites intelectuales y modelos colectivos. Mundo Ibérico (siglos XVI-XIX), Consejo Superior de Investigaciones Científicas-Instituto de Historia-Departamento de Historia de América, Madrid, 2002, págs. 199-218. Respecto de las reformas que afectaron al clero, tema que ha sido ya ampliamente estudiado por la historiografía reciente sobre la Nueva España, podemos destacar: Farriss: Clero y Corona...; Mazín, Óscar: Entre dos majestades. El obispo y la Iglesia del Gran Michoacán ante las reformas borbónicas, 1758-1772, El Colegio de Michoacán, Zamora,1987; Mazín, Óscar: El cabildo catedral de Valladolid de Michoacán, El Colegio de Michoacán, Zamora, 1996; Brading, David A.: Una Iglesia asediada: el obispado de Michoacán, 1749-1810, Fondo de Cultura Económica, México, 1994; Jaramillo Magaña, Juvenal: Hacia una Iglesia beligerante. La gestión episcopal de Fray Antonio de San Miguel en Michoacán (1784-1804). Los proyectos ilustrados y las defensas canónicas, El Colegio de Michoacán, Zamora,1996; Zahino Peñafort, Luisa: Iglesia y sociedad en México, $1765-$ 1800. Tradición, reforma y reacciones, Instituto de Investigaciones Jurídicas-Universidad Nacional Autónoma de México, México, 1996; Taylor, William: Ministros de lo sagrado. Sacerdotes y feligreses en el México de la segunda mitad del siglo XVIII, 2 vols., El Colegio de Michoacán/Secretaría de Gobernación/El Colegio de México, Zamora, 1999; Torre Curiel, José Refugio de la: Vicarios en entredicho. Crisis y desestructuración de la Provincia Franciscana de Santiago de Xalisco, 1749-1860, El Colegio de Michoacán/Universidad de Guadalajara, México, 2001. 
rada aplicación , la oposición decidida a las más radicales ${ }^{9}$ y su fundamento dentro del propio sistema político entonces vigente. De hecho, en diversas ocasiones las reformas fortalecieron más que debilitaron el régimen tradicional al otorgar nuevos fueros y privilegios, crear nuevas corporaciones y respaldar algunos de los ya existentes..$^{10}$ Así, podemos decir siguiendo a Annick Lempérière:

“...triunfó entre mediados y finales del siglo XVIII, en Nueva España, un modelo neoabsolutista que, sin dejar de ser ilustrado, fue a final de cuentas moderado y prudente en la implementación de las novedades teóricas en que se fundamentaba." ${ }^{11}$

Así pues, no puede extrañar que la creación de nuevas diócesis en la Nueva España se mantuviera claramente en este contexto jurídico e institucional.

\section{"La primera y mas antigua Ciudad de este basto Reyno"}

El 9 de agosto de 1799, D. Ramón de Posada, fiscal del Supremo Consejo y Cámara de Indias, expuso al Consejo:

“...que por los conocimientos que havia adquirido en 14 años que sirvió en Mexico las Fiscalias de aquella Audiencia y Gobierno, y por lo que havia oido à sugetos imparciales y muy practicos de los territorios de sus Obispados, llegó a formar juicio de que era absolutamente necesario para el buen servicio de Dios y de V.M. que se erigiesen otros tres mas en el Distrito de aquel Virreinato." ${ }^{12}$

Los nuevos obispados se ubicarían: uno en la costa sur (actual territorio del Estado de Guerrero), otro en la costa norte (es decir, las costas del Golfo de México), y el tercero en la provincia de San Luis Potosí. El Consejo, por Real Cédula del 20 de mayo de 1800, solicitó al virrey de la

9 En el caso de la Iglesia, Mazín: El cabildo catedral..., págs. 387-391 y Magaña: Hacia una..., págs. 83-110, presentan la oposición a la reforma más importante: el control de los diezmos, establecido por la Ordenanza de Intendentes de 1789, y suspendida por la oposición conjunta de las Iglesias novohispanas.

10 Lempérière, Annick: "Reflexiones sobre la terminología política del liberalismo", en Connaughton, Brian, Carlos Illades y Sonia Pérez Toledo (coords.): La construcción de la legitimidad política en México, El Colegio de Michoacán/Universidad Autónoma Metropolitana-Unidad Iztapalapa/Universidad Nacional Autónoma de México/El Colegio de México, México, 1999, págs. 35-56.

11 Lempérière: "La recepción negativa...”, pág. 218.

12 AGI, México, 2603. Consulta del Consejo y Cámara de Indias en pleno de las tres salas, Madrid, 15 de diciembre de 1807. 
Nueva España que recabase la información necesaria para trazar los límites y ubicar las sedes de las nuevas diócesis. No pasó mucho tiempo antes de que las ciudades y villas de los territorios involucrados remitiesen amplias representaciones al rey pidiendo, ya que se efectuara de manera expedita la creación de los obispados, ya que se les designara para las nuevas sedes episcopales. El Ayuntamiento de la Ciudad de Veracruz envió la suya el 22 de diciembre de 1802, recordando una solicitud anterior, de 1789, en la que habían solicitado la división de la diócesis de Tlaxcala, con sede en la Puebla de los Ángeles, fundando la petición bajo el criterio de la necesidad, por: "el poco auxilio que disfrutan varias Poblaciones de las comprehendidas en el Obispado de la Puebla por su basta estencion"; ${ }^{13}$ sugerían además la oportunidad de la medida, aprovechando la vacante motivada por el fallecimiento del obispo Dr. Salvador Biempica y Sotomayor. Además de la división, presentaban argumentos para que la nueva sede episcopal se instalase en su ciudad, en principio: "por ser esta la primera y mas antigua Ciudad de este basto Reyno, donde su heroyco conquistador Dn. Fernando Cortés sembró las primeras semillas del Evangelio, y se rindiò á la obediencia del Rey Catolico." Y asimismo, por lo "civilizado y brillante" de su vecindario. ${ }^{14}$ Ciertamente expusieron de nueva cuenta la necesidad, por la falta de asistencia espiritual que padecía la ciudad, y la utilidad, por facilitarse al obispo visitar su diócesis desde Veracruz; puntos que habrían de presentar una y otra vez en los años siguientes; mas en ésta, como en sus sucesivas representaciones, el primer alegato en su favor fue el honor de la ciudad, agregándose su condición de capital de provincia.

En efecto, en 1804 y 1806, el representante legal del Ayuntamiento, Manuel de Quevedo y Bustamante, contestó a las objeciones que, con motivo del malsano clima porteño, podían oponer los ayuntamientos de las villas cercanas, Córdoba y Orizaba, destacando la condición de ciudad capital; es decir, sede permanente de oficinas, corregimiento, consulado, intendencia, plaza de armas, sin que para ello obstaran las condiciones climáticas. ${ }^{15}$ Así fue también por parte del propio Ayuntamiento, que acusó a

13 AGI, México, 2603. Representación del Ayuntamiento de Veracruz del 22 de diciembre de 1802, copia hecha en Veracruz, 10 de abril de 1813.

14 AGI, México, 2603. Representación del Ayuntamiento de Veracruz del 22 de diciembre de 1802, copia hecha en Veracruz, 10 de abril de 1813.

15 AGI, México, 2603. Representación de D. Manuel de Quevedo y Bustamante, apoderado del Ayuntamiento de Veracruz, Madrid, 31 de agosto de 1804. Representación de D. Manuel de Quevedo y Bustamante, apoderado del Ayuntamiento de Veracruz, Madrid, 1 de marzo de 1806, copia hecha en Veracruz, 10 de abril de 1813. 
sus rivales de ver sólo por su engrandecimiento, y por ello "afectaban perder de vista la preponderancia de los respetos de una Ciudad (...) Capital de la Prov.a y residencia de las autoridades civiles, politicas y militares". ${ }^{16}$

El advenimiento del liberalismo en la segunda década del siglo XIX no dio motivo a un cambio inmediato en los argumentos de los notables porteños. A las cortes de 1813 se dirigió otra vez una representación, motivada por la nueva vacante de la sede episcopal poblana, sin variar los argumentos, incluyendo sólo los méritos recién adquiridos por su comercio, por los cuales la sede episcopal debía situarse en Veracruz:

"tanto por ser la Ciudad mas antigua de esta N.E. cuyo impulso facilitó su conquista, como por ser la residencia del Gefe de la Provincia, la de las Caxas del Erario y demas oficinas principales de los Ramos de la Hacienda Nacional, como por ser Plaza de Armas y estar establecido en ella su Tribunal del Consulado, cuyo comercio terrestre y maritimo por su vasto giro desde el establecimiento del comercio libre ha dado movimiento á todo el resto del Reyno, y la ha hecho una de las ciudades de mayor tráfico y extensas conexîones en el y en la Peninsula". ${ }^{17}$

Mas ninguna de estas exposiciones tuvo una respuesta favorable. Hemos citado que una autoridad en la jurisprudencia indiana como Solórzano Pereira establecía como criterios para la creación de nuevas diócesis la necesidad, utilidad y el consentimiento de los obispos, y precisamente fue éste el obstáculo para el logro de las aspiraciones de los veracruzanos. El proceso para la creación de nuevas diócesis sufrió un largo retraso pues en cuatro años no hubo respuesta del virrey que remitiera la información necesaria, sino hasta luego de un recordatorio del Consejo de Indias. Cuando finalmente el virrey de la Nueva España, D. José de Iturrigaray, respondió al Consejo, el 27 de marzo de 1804, atribuyó tan pronunciada tardanza en la instrucción del expediente a las dilaciones del gobierno eclesiástico poblano para remitir los datos que "de ruego y encargo" se le habían solicitado en $1800 .{ }^{18}$ En efecto, la mitra y el Cabildo Catedral de la Puebla de los Ángeles se opusieron, con los medios a su alcance, a la separación de los diezmatorios que se esperaba se integrarían a la diócesis de Veracruz, los de las villas de Córdoba, Orizaba y Xalapa.

16 AGI, México, 2603. Representación del Ayuntamiento de Veracruz, sin fecha, copia hecha en Veracruz, 10 de abril de 1813.

17 AGI, México, 2603. Representación del Ayuntamiento de Veracruz a las Cortes Generales y Extraordinarias, Veracruz, 10 de abril de 1813.

18 AGI, México, 2603. Consulta del Consejo y Cámara de Indias en pleno de las tres salas, Madrid, 15 de diciembre de 1807. 
Según parece, el alto clero poblano no tuvo dificultad para enterarse de que habría de ser acusado de obstruir la voluntad regia. Apenas unas semanas más tarde, el 27 de abril, el obispo D. Manuel Ignacio González del Campillo remitió a la Corte una representación en defensa del proceder del gobierno de la mitra denunciando la connivencia entre el virrey y el comercio de Veracruz para establecer una nueva sede diocesana en Veracruz, sin considerar, según los eclesiásticos, el bien común del reino. ${ }^{19}$ Para septiembre de 1805 el obispo y su Cabildo enviaron además una extensa representación con mayores argumentos sobre los perjuicios que acarrearía tanto la ubicación de la nueva sede como la división propuesta. ${ }^{20}$ Largo sería aquí reseñarlos todos, aunque sin duda tuvieron un peso efectivo en el Consejo. Por resolución del pleno de las tres salas, el 15 de diciembre de 1807, se dictaminó que la creación del nuevo obispado de Veracruz "no se halla en estado de poder resolverse", ${ }^{21}$ como no se resolvió tampoco por las cortes de 1813-1814, que recibieron la última de las representaciones del ayuntamiento porteño hasta aquí citadas.

Como puede observarse, los munícipes veracruzanos habían hecho casi una costumbre buscar la división del obispado en el marco de la sedes vacantes. La última de las que tuvieron lugar bajo el gobierno virreinal fue la del doctor González del Campillo, en cuyo marco se envió la última de las representaciones hasta aquí citadas. Así pues la situación se mantuvo sin cambios hasta el inicio del nuevo régimen, mas antes de pasar a considerarlo, conviene detenernos en un actor ausente de la discusión hasta aquí planteada:

\section{El clero secular veracruzano}

Como en toda la Iglesia del Antiguo Régimen, el clero veracruzano era fundamentalmente urbano. Cuatro eran las principales urbes veracruzanas: las villas de Orizaba, Xalapa y Córdoba, y la ciudad y puerto de Veracruz. Entre las últimas décadas del siglo XVIII y las primeras del XIX, el clero de las tres villas fue relativamente numeroso, sobre todo en Orizaba; en cambio, en el puerto, aunque al mediar el siglo era similar en número,

19 AGI, México, 2603. D. Manuel Ignacio González del Campillo a D. José Antonio Caballero, Puebla, 27 de abril de 1804.

20 AGI, México, 2603. D. Manuel Ignacio González del Campillo al Príncipe de la Paz, Puebla, 26 de septiembre de 1805.

21 AGI, México, 2603. Consulta del Consejo y Cámara de Indias en pleno de las tres salas, Madrid, 15 de diciembre de 1807. 
padeció una disminución importante. José Antonio de Villaseñor y Sánchez apuntaba en 1746 que en Veracruz y Orizaba había más de 30 presbíteros, en Córdoba cerca de 20, y en Xalapa apenas contaba un cura y su vicario. ${ }^{22}$ Hacia el cambio de siglo, mientras que en Orizaba fueron empadronados 20 clérigos en $1791,,^{23}$ once años más tarde, en 1802, el ayuntamiento porteño lamentaba la falta de asistencia de su parroquia, con tan sólo el cura párroco, dos tenientes y un capellán de extramuros. ${ }^{24}$ Tras la independencia, y de acuerdo a la información remitida por la mitra de Puebla al gobierno imperial en 1823, en Xalapa y en Orizaba residían unos veintidós clérigos, en Córdoba llegaban a quince y en el puerto apenas a doce. ${ }^{25}$ Es posible que el clero hubiera mantenido cierta estabilidad en sus tendencias, e incluso aumentado, pues para 1824 fueron contados 29 presbíteros en Orizaba; ${ }^{26}$ cabe tener presente que la diócesis de Puebla no se vio afectada por las largas vacantes episcopales que padecieron otras diócesis. ${ }^{27}$

Todos estos clérigos contaban, claro está, con mecanismos para manifestarse. En Orizaba por ejemplo existía un congregación de San Pedro que reunía a la mayor parte de los clérigos presbíteros y de órdenes menores de la parroquia, y que podía hablar en nombre del Venerable Clero; ${ }^{28}$ desconocemos si existía una corporación similar en las otras parroquias, si bien a mediados del siglo XIX el clero secular de Xalapa representó como cuer-

22 Villaseñor y Sánchez, José Antonio: Theatro Americano. Descripción general de los Reynos y Provincias de la Nueva-España y sus jurisdicciones, Editora Nacional, 1952, págs. 258, 265, 271 y 282.

23 Valle Pavón, Guillermina: "Ocupación y especialización en la villa de Orizaba en 1791”, en Contreras Cruz, Carlos y Carmen Blázquez Domínguez (coords.): De costas y valles. Ciudades de la provincia mexicana a finales de la colonia, Benemérita Universidad Autónoma de Puebla, Puebla, 2003, págs. 206-210.

24 AGI, México, 2603, Representación del Ayuntamiento de Veracruz del 22 de diciembre de 1802, copia hecha en Veracruz, 10 de abril de 1813.

25 AGN, Justicia Eclesiástica, 22, fs. 315-326, "Nota de los Eccos. del clero secular de toda la Diocesis de Puebla, con espresion del luger de su residencia, titulo á que están ordenados, destinos de que subsisten, é igualmente de los empleos Eclesiásticos ò civiles que estàn y la industria ô comercio â que están dedicados".

26 AHMO, 27, secc. Gobierno, "Estado que manifiestan los curatos, parroquias, conventos y capillas que tiene este partido con espresion e sus fincas rusticas y urbanas, sus imposiciones y reditos", 1824.

27 Conviene recordar que, con motivo de las dificultades para nombrar obispos una vez desaparecido el patronato con la independencia, la diócesis de Michoacán estuvo vacante de obispos consagrados desde 1809 hasta 1831 , y de obispo electo desde 1815 hasta esta última fecha; el arzobispado de México estuvo también vacante desde 1822 hasta 184-, la diócesis de Oaxaca desde 1827 hasta 18 Puebla, en cambio, sólo estuvo vacante entre abril de 1829 y junio de 1831 .

28 Sobre este tipo de congregaciones clericales véase: Asunción Lavrín: "La Congregación de San Pedro. Una cofradía urbana del México colonial - 1604-1730”, Historia Mexicana, Vol. 29, Núm. 4, 1980, págs. 562-601. 
po ante las propuestas sobre la ocupación de bienes eclesiásticos de $1846,{ }^{29}$ por lo que podemos suponer que, en caso de necesidad, los párrocos podían reunir así, "en cabildo", a sus vicarios, capellanes y demás presbíteros y diáconos para tratar asuntos del interés de todos. Los clérigos veracruzanos bien hubieran podido organizarse y emplear la vía de la representación para expresar su posición en la creación de la nueva diócesis; sin embargo, es muy posible que no tuviesen grandes incentivos para hacerlo.

$\mathrm{Al}$ respecto debemos recordar que en los clérigos de la época se advierte una doble tendencia, por una parte, tanto por sus orígenes familiares y sociales como por su labor desarrollada en un marco fundamentalmente urbano, mantenían una relación muy cercana con las élites de sus ciudades, e incluso en algunos casos le daban coherencia a lo que éstas se interesaban en transmitir, hasta un punto en que su identificación regional posiblemente llegaba a impedir esfuerzos de conjunto en marcos más amplios. ${ }^{30}$ Ciertamente, los clérigos de las ciudades eran con frecuencia hijos de los vecinos "de distinción", se ordenaban gracias a las capellanías heredadas de familiares de antaño o fundadas ex profeso para ellos, o incluso a título de su propio patrimonio; los ayuntamientos, las corporaciones que integraban esas élites locales y regionales, estaban al pendiente de los nombramientos de los curas párrocos, les encargaban piezas de oratoria para las grandes solemnidades, trabajaban con ellos en proyectos comunes - templos desde luego, pero también hospitales y escuelas, que seguían siendo entendidas como "obras pías"- e incluso se encontraban juntos como particulares en algunas compañías. ${ }^{31}$ Por ello no es de extrañar que en todo el expediente sobre el tema del nuevo obispado sólo se ventilara el nombre de un eclesiástico favorable a las representaciones de los ediles: el cura párroco porteño D. Ramón Palao, que según el obispo González del Campillo era visto por el ayuntamiento como un posible candidato para primer titular de la nueva sede. ${ }^{32}$

29 Trens, Manuel B.: Historia de Veracruz, tomo V, Gobierno del Estado de VeracruzSecretaría de Educación y Cultura, Xalapa, 1992, págs. 215-216.

30 En diversos trabajos Brian Connaughton ha insistido en este punto, véanse principalmente los ensayos reunidos en su obra Dimensiones de la identidad patriótica. Religión, política y regiones, siglo XIX, Universidad Autónoma Metropolitana-Unidad Iztapalapa/Grupo Editorial Miguel Ángel Porrúa, (Biblioteca de Signos), México, 2001, 252 págs, en particular págs. 16-29, 31-52, 137-165.

31 El estudio más completo sobre los curas párrocos de fines del siglo XVIII es Taylor, William: Ministros de lo sagrado. Sacerdotes y feligreses en el México de la segunda mitad del siglo XVIII, 2 vols., El Colegio de Michoacán/Secretaría de Gobernación/El Colegio de México, Zamora, 1999, vol. 1.

32 AGI, México, 2603, D. Manuel Ignacio González del Campillo a D. Joseph Antonio Caballero, Puebla, 27 de abril de 1804. 
Mas si lo miramos desde otro ángulo, no es menos cierto que con cierta regularidad el clero estaba también estrechamente relacionado con la capital de su obispado. Había, evidentemente, razones institucionales para ello, los clérigos veracruzanos normalmente habían estudiado en el seminario poblano y, una vez graduados, era común que los contasen con algún apoderado en la curia episcopal, para tramitar la colación de alguna capellanía o de un curato; o bien, que algunos de los clérigos que durante su carrera hubiesen trabajado en las villas, y pueblos circundantes, culminasen su "carrera" con un cargo en el Cabildo catedralicio o en la mitra. Así fue, por sólo citar algunos ejemplos, con el cura de Orizaba, D. Melchor Álvarez Carballo, a fines del siglo XVIII, ${ }^{33}$ con D. José Manuel Couto, orizabeño que ocupaba una media ración en la catedral poblana en $1823,{ }^{34} \mathrm{o}$ con el ex cura de Xalapa, D. Mariano José Cabofranco, ${ }^{35} \mathrm{e}$ incluso podríamos pensar aquí en el propio Dr. Francisco Pablo Vázquez, cura de Coatepec entre 1797 y 1798, que llegó a obispo de Puebla en 1831 luego de haber sido representante de México ante la sede apostólica.

Así pues, con un clero que, aunque disperso, estaba ligado de manera importante a su catedral, y siendo más bien reducida la presencia del clero secular en la ciudad de Veracruz — que sin duda hubiera sido realmente el interesado directo en la erección- no es extraño que el clero veracruzano no hubiese participado en el tema de la nueva diócesis, ni bajo la monarquía católica, ni tampoco bajo el republicanismo, también católico, del que trataremos a continuación.

\section{México: nación católica, nación de estados}

Entre 1821 y 1857 los distintos proyectos formulados para la construcción de una nación mexicana tuvieron un punto de partida común: el principio confesional. La nación era católica, no toleraba el ejercicio de

33 Cruz Soto, Irma Guadalupe: “Querellas de cabildos en la 'Garganta del Reyno': indios y españoles en Orizaba al final de la Colonia”, La palabra y el hombre, Núm. 99, 1996, pág. 44.

34 AGI, México, 2652. Memoriales de Pretendientes a dos medias raciones de Puebla, 1806. Memorial de D. Joseph Manuel de Couto al Ministro de Gracia y Justicia de Indias, Madrid, 1 de noviembre de 1806 .

35 El listado del Cabildo Catedral poblano en 1823 puede verse en: AGN, Justicia Eclesiástica, 22, fs. 315-326, "Nota de los Eccos. del clero secular de toda la Diocesis de Puebla, con espresion del luger de su residencia, titulo á que están ordenados, destinos de que subsisten, é igualmente de los empleos Eclesiásticos ò civiles que estàn y la industria ô comercio â que están dedicados". 
ningún otro culto y se obligaba a proteger a la Iglesia a través del respeto a su fuero particular. En contrapartida, la Iglesia aceptaba la intervención del gobierno en los nombramientos eclesiásticos, respaldaba sus necesidades financieras y colaboraba en la construcción de una identidad mexicana. ${ }^{36}$

Este esquema respondía a la particular vía en la que el antiguo virreinato se hizo independiente. Ante la legislación anticlerical de las cortes españolas del "trienio liberal", las élites novohispanas trataron de construir una forma de gobierno que conciliara la preeminencia de la religión católica y el nuevo constitucionalismo liberal. Las garantías de religión, independencia y unión del plan de Iguala, base fundamental del primer imperio y de la república federal y centralista subsecuentes, constituían precisamente "la promesa de establecer un régimen constitucional formal que respetase en materia religiosa la constitución histórica de la Nueva España". ${ }^{37}$

La jerarquía católica apoyó este proyecto, aunque con diversos matices entre una diócesis a otra. Desde los primeros años de vida independiente, el apoyo al régimen comprendió no sólo aportaciones económicas, sino además muestras de lealtad a la independencia que superaban incluso la lealtad a Roma. Un ejemplo clásico a este respecto fue el rechazo unánime de los obispos ante el contenido de la encíclica Etsi iam Diu del Papa León XII, que condenaba las independencias hispanoamericanas. ${ }^{38}$ Asimismo, la Iglesia contribuyó a construir, al interior del país, tanto la lealtad hacia el gobierno, promoviendo su respeto, aun en los momentos de crisis de su relación, ${ }^{39}$ como la difusión del principal símbolo nacio-

36 Véase: Connaughton, Brian: "El ocaso del proyecto de `Nación Católica’. Patronato virtual, préstamos y presiones regionales, 1821-1856", en Connaughton, Brian, Carlos Illades y Sonia Pérez Toledo (coords.): La construcción de...págs. 227-262. Conviene hacer notar que este período la construcción de una identidad no se planteó como elemento primordial de la nueva nación, toda vez que durante la mayor parte del siglo XIX mexicano el problema de la nación se planteó como un problema exclusivamente político y no tanto histórico-cultural.

37 Arenal Fenochio, Jaime: "El Plan de Iguala y la salvación de la Religión y de la Iglesia novohispana dentro de un orden constitucional", en Ramos Medina, Manuel (comp.): Memoria del I Coloquio "Historia de la Iglesia en el siglo XIX", El Colegio de México/El Colegio de Michoacán/Instituto Mora/Universidad Autónoma Metropolitana-Unidad Iztapalapa/Centro de Estudios de Historia de México CONDUMEX, México, 1998, pág. 77.

38 Véase: Gómez Ciriza, Roberto: México ante la diplomacia vaticana. El período triangular (1821-1836), Fondo de Cultura Económica, México, 1977.

39 A través de sus sermones, el clero, en palabras de Brian Connaughton, "se orientaba a la validación del compromiso, inherente a la Constitución de 1824, entre soberanía popular y fuero eclesiástico", Connaughton, Brian: "El clero y la fundamentación del Estado-Nación Mexicano", en Connaughton, Brian y Andrés Lira (coords.): Las fuentes eclesiásticas para la historia social de México, Universidad Autónoma Metropolitana-Iztapalapa/Instituto de Investigaciones Dr. José María 
nal: la virgen de Guadalupe. Desde 1822, los representantes diocesanos aceptaron además la participación gubernamental en la provisión de beneficios eclesiásticos, no a través del antiguo patronato real, que fue declarado extinto, sino mediante el ejercicio de la exclusiva por parte del Poder Ejecutivo. ${ }^{40}$

Los gobiernos que se sucedieron en esta época confirmaron, por su parte, la identidad católica de la nueva Nación, fundamentalmente a través de las fiestas. Como ha destacado Annick Lempérière, durante esta época "la práctica política busca la sacralización religiosa", y aún más, "la religión católica sigue cumpliendo el papel de lazo político que tenía bajo los auspicios de la monarquía española" ${ }^{41}$ En consecuencia, desde el propio 27 de septiembre de 1821, los nuevos "mexicanos" celebraron con Te Deum y misa solemne tanto las festividades patrióticas relacionadas con la independencia, como los juramentos constitucionales y las abundantes proclamaciones y pronunciamientos de la época, que vinieron a sumarse a las fiestas religiosas en las que siguieron concurriendo las nuevas autoridades

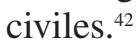

Sin embargo, ello no evitó que en ciertos momentos las relaciones entre las "dos potestades" llegaran a ser tensas. El panorama se complicó entre 1823 y 1835, cuando las antiguas provincias del virreinato de la Nueva España se constituyeron en estados libres y soberanos. En consecuencia, no sólo era necesario construir lealtades en torno a la Nación, sino también en torno a cada una de las nuevas entidades políticas. La articulación entre la nación, los estados y la Iglesia tuvo forzosamente que modificarse en líneas no previstas por los jerarcas eclesiásticos; los problemas que éstos no habían tenido en el ámbito nacional los tuvieron en el caso de los estados, a los que posiblemente identificaban como intentos de control

Luis Mora, México, 1996, pág. 359. Incluso las pastorales emitidas por los obispos con motivo de la primera reforma liberal (1833-1834) coincidían en indicar a los fieles y al clero de las diócesis que mantuvieran su fidelidad al gobierno, véase Colección Eclesiástica Mejicana, Imprenta de Galván a cargo de Mariano Arévalo, 1834, tomos 3 y 4.

40 Véase: "Acta de la junta de Diocesanos celebrada en Mégico el año de 1822", en Rodríguez de San Miguel, Juan: Pandectas Hispano-Megicanas, Instituto de Investigaciones JurídicasUniversidad Nacional Autónoma de México, México, 1991, tomo I, págs. 350-355.

41 Lempérière: "Reflexiones..., págs. 146-147.

42 Cabe decir que el ciclo de festejos fue particularmente intenso en las principales urbes veracruzanas, la villa de Xalapa y la ciudad y puerto de Veracruz, ligadas estrechamente al general Antonio López de Santa Anna, el político más festejado de la época. Sobre las innumerables fiestas con misas de acción de gracias y Te Deum que se le dedicaron en Xalapa en esta época véase Fowler, Will: "Fiestas Santanistas: La celebración de Santa Anna en la Villa de Xalapa, 1821-1855", Historia Mexicana, vol. LII, no. 2, México, 2002, págs. 413-440. 
de la Iglesia y/o secularización de la sociedad. ${ }^{43}$ Algunos de los obispos y clérigos que por entonces participaban en la política posiblemente hayan previsto tales peligros, pues resulta notoria la filiación de algunos de ellos a la oposición centralista. ${ }^{44}$

Mas no debe creerse a priori que los nuevos estados tomarían posición desde el inicio como una fuerza anticlerical; antes bien, suscribieron en sus constituciones el respeto a los lineamientos nacionales a favor de la religión católica y de la Iglesia; de hecho, en la mayoría de los casos los políticos estatales de todos los bandos se presentaron a sí mismos como protectores de la religión, como indica Lempérière "la afirmación de la república católica formó parte de los argumentos empleados en las luchas políticas del momento". ${ }^{45}$ Más que afectar explícitamente el pacto con la Iglesia, los estados normalmente tendían a ganar terreno ante las facultades de la federación, lo que no evitó que en ciertos temas hubiera conflictos directos con los obispos y cabildos catedrales, como sucedió en Veracruz entre 1824 y 1825.

\section{4: entre el honor de la soberanía y el pacto con la Iglesia}

En mayo de 1824 se instaló en la villa de Xalapa el Congreso Constituyente del estado de Veracruz. Entre julio y noviembre de ese año, el Congreso intentó ejercer su nueva soberanía en tres temas que motivaron los conflictos con los eclesiásticos, particularmente con el obispo de la Puebla de los Ángeles, Antonio Joaquín Pérez Martínez. ${ }^{46}$ Los legisladores

43 Posiblemente llevaban razón en esa perspectiva, pues el propio doctor José María Luis Mora veía en los Estados "el más fuerte y poderoso impulso que ha recibido la ilustración nacional", entendida como focos de modernidad política. Citado por Lempérière, Annick: “Nación moderna o República barroca? México, 1823-1857”, Imaginar la Nación, Asociación de Historiadores Latinoamericanistas Europeos, 1994, págs. 141-142.

44 Centralistas fueron clérigos de la diócesis poblana como José Miguel Guridi y Alcocer, de Tlaxcala, y José María Becerra, de Xalapa, según el estudio de David Quinlan sobre la composición de los grupos políticos del Congreso Constituyente de 1823-1824, citado en Ávila, Alfredo: En nombre de la nación. La formación del gobierno representativo en México (1808-1824), Taurus/Centro de Investigación y Docencia Económicas, México, 1999, págs. 312-313.

45 Lempérière: “¿Nación moderna...?”, pág. 151.

46 El obispo Pérez Martínez tenía tras de sí una larga carrera en los asuntos públicos. Fue diputado a las Cortes de Cádiz, siendo recordado en particular por su participación en el "Manifiesto de los Persas", que solicitaba a Fernando VII que restableciese el absolutismo. Nombrado obispo de Puebla en 1814, se destacó por su oposición al gobierno del virrey Félix María Calleja. En 1821 apoyó el pronunciamiento de Agustín de Iturbide, participando en la Junta Provisional Gubernativa que se formó tras la entrada del Ejército Trigarante a la Ciudad de México. En 1823 se opuso a la constitución adelantada de un Estado libre y soberano en Puebla, apoyando, junto con el Cabildo Catedralicio, la postura que atribuía tal decisión al Congreso nacional. 
expidieron decretos reglamentando la formación de aranceles parroquiales, prohibiendo los responsos, las ofrendas y las procesiones nocturnas, la colectación de limosnas y la venta de reliquias; se apropiaron del ejercicio del derecho de exclusiva en la provisión de los beneficios eclesiásticos y suprimieron la inmunidad local en la Constitución estatal. ${ }^{47}$ En los tres casos hubo protestas del obispo poblano, que cuestionaba las facultades de la nueva entidad política para intervenir en asuntos que se entendían propios del ámbito nacional. ${ }^{48}$

Como respuesta a los cuestionamientos episcopales, el 17 de noviembre de 1824 el Congreso veracruzano dirigió al Congreso federal una representación encaminada a poner fin a los debates con los Obispos. Los constituyentes veracruzanos demandaban que el Congreso federal, según sus facultades, o a través del enviado ante la Silla Apostólica, estableciera un vicario general con jurisdicción en todo el territorio veracruzano, y con autonomía respecto de los tres diocesanos de México, Puebla y Oaxaca. Alegaban que la división eclesiástica corría el riesgo de dejar en ridículo la soberanía, "una e indivisible", que se hallaba depositada en ellos como representantes de los pueblos. En apoyo de esa solicitud afirmaban de forma contundente: "La potestad eclesiástica y el ejercicio de su jurisdicción forman una parte de la administración del Estado...". Lo que no evitaba que se refirieran al ideal de la relación siguiendo el viejo lenguaje de las "dos potestades", civil y eclesiástica, con supremacía de la primera, para que ambas "caminen enteramente acorde(s) ...para hacer el bien y la felicidad de los hombres", ${ }^{49}$ es decir, para el bien común, según un concepto de larga tradición en el pensamiento cristiano.

Según los congresistas, los jerarcas eclesiásticos "por la distancia y sus infinitas atenciones" no estaban en posibilidad siquiera de realizar visitas pastorales. Además, y sobre todo, los prelados "no pueden siempre pensar de un mismo modo en ciertos puntos relativos á la administración espi-

47 Decreto núm. 19 del Congreso Constituyente del Estado de Veracruz, "Sobre la formación de aranceles parroquiales y prohibición de ofrendas, responsos nocturnos, etc.", 17 de agosto de 1824. Decreto núm. 27 del Congreso Constituyente del Estado de Veracruz, "El Gobierno del Estado debe ejercer la exclusiva en la provisión de piezas eclesiásticas", 16 de noviembre de 1824, ambos en Blázquez Domínguez, Carmen y Ricardo Corzo Ramírez (comps.): Colección de Leyes y Decretos de Veracruz, 1824-1919, Universidad Veracruzana, Xalapa, 1997, tomo I, págs. 89-90 y 185.

48 Véase el expediente correspondiente: AGN, Justicia Eclesiástica, 44, "Sre. la cuestion movida por el Congo. de Veracruz sre. aranceles de dros. parroquiales", fs 336-341.

49 Copia de la exposición dirigida al Congreso de la Unión por el Congreso Constituyente del Estado de Veracruz el 19 de noviembre de 1824, AGN, Justicia Eclesiástica, 147, "Bula pontificia sobre la erección de una Mitra en el Departamento de Veracruz", f. 241. 
ritual (...) Es tan cierto, que el Congreso no habla sino por una dolorosa experiencia: no siempre la Ley que agrada a un Prelado, es conforme con las ideas de los otros...." ${ }^{50}$ Desde luego, aludían a su relación con los obispos, particularmente con el de Puebla.

Conviene recordar, en este escenario de conflicto, que el Congreso veracruzano no aplicaba una política ni de sistemático control del clero, ni menos aún anticlerical. Independientemente de las "contestaciones" tenidas con el obispo poblano, el Congreso había ido emitiendo decretos y órdenes en materias eclesiásticas locales que fueron aceptados por los mitrados. Se trataron desde quejas con respecto a la conducta de algunos curas párrocos — remitidas, por lo común, a la jurisdicción de los obispos- hasta la apropiación de las rentas decimales que antes pertenecían a la Corona. ${ }^{51}$ Asimismo, los legisladores veracruzanos dejaron claro, desde el inicio de sus sesiones, la trascendencia de la religión en la vida pública convocando a rogativas en todas las parroquias del territorio para llevar a

50 Copia de la exposición dirigida al Congreso de la Unión por el Congreso Constituyente del Estado de Veracruz el 19 de noviembre de 1824, AGN, Justicia Eclesiástica, 147, "Bula pontificia sobre la erección de una Mitra en el Departamento de Veracruz", f. 241v.

51 Véanse los Decretos del Congreso Constituyente del Estado de Veracruz, número 14 del Congreso Constituyente del Estado de Veracruz, "Sobre las rentas civiles provenientes de las eclesiásticas que pertenecen al Estado", 12 de julio de 1824, y número 23. "Ley contra la circulación de libros prohibidos y estampas obscenas", 4 de septiembre de 1824, ambos en Blázquez Domínguez y Corzo Ramírez: Colección de Leyes..., tomo I, págs. 62-63 y págs. 108-109 respectivamente. Asimismo, las órdenes del Congreso Constituyente del Estado de Veracruz, del 4 de agosto de 1824, "Para que se ponga en asta (sic) pública la casa llamada curatal de Tlacotalpan"; del 6 de agosto de 1824, "Sobre que el Ayuntamiento de Ozuluama ocurra á la haceduría de México con la solicitud de que se rebaje el diezmo á las crías de ganado"; de la misma fecha, "Remitiendo al Gobierno para su despacho el ocurso del Ayuntamiento de Jico quejándose contra su párroco"; de 9 de agosto de 1824, "Varias providencias relativas á la queja del Ayuntamiento de Tantima contra su párroco"; del 23 de septiembre de 1824, "Sobre que no ha lugar á que se publique por la imprenta en el ocurso del párroco de Jicochimalco, relativo á la queja de sus feligreses"; del 21 de octubre de 1824, "Sobre la resistencia del párroco de Tlacotalpan á entregar al Ayuntamiento la casa que habita"; del 22 de octubre de 1824, "Para que se haga saber al regidor de la ranchería de Quiahuiscuatla el desagrado con que el Congreso ha visto la calumniosa representación que se cita"; del $1^{\circ}$ de diciembre de 1824, "Para que se le extrañe al Ayuntamiento de Tlacotalpan el informe que dio sobre que aquel párroco continuaba haciendo clasificación de orígenes en los libros é instrumentos públicos de su curato"; del 18 de febrero de 1825, "Sobre que la Iglesia, vasos sagrados y utensilios del convento de belemitas de Veracruz se entregue al párroco de aquella ciudad; las fincas rústicas y urbanas se depositen bajo las formalidades de derecho, y que á los religiosos de dicha orden se les atienda con treinta pesos al mes"; del 18 de marzo de 1825, "Sobre la queja del Alcalde del pueblo de Tecominuacan contra el párroco del mismo"; del 21 de abril de 1825 "Para que se abonen al cura de Tempoal los 800 pesos que por vía de sínodo ha disfrutado por sí y para la dotación de un vicario en el pueblo de Tancuich"; del 4 de mayo de 1825, "Para que se observe la costumbre en Zongolica en orden al pago de diezmos que se menciona, y sólo contesten, en caso de demanda, ante el tribunal de segunda instancia del Estado" todos en Blázquez Domínguez y Corzo Ramírez: Colección de Leyes..., tomo I, págs. 84, 87-88, 92, 118, 176-177, 240-241, 250-251, 264, 270-271. 
buen fin su misión..$^{52}$ Durante toda la década siguiente seguirían siendo usuales en las urbes veracruzanas las fiestas religiosas en las que participaba las autoridad civil, y las fiestas cívicas, nacionales y locales, en las que la religión tenía un papel primordial. En ese sentido, los legisladores veracruzanos no ponían en cuestión el pacto entre la Nación y la Iglesia, pues respetaban su jurisdicción, e incluso apoyaron económicamente algunas de sus corporaciones.

No obstante, el constituyente veracruzano era ya la representación de un Estado en el sentido moderno del término. Legitimado por una elección y en posesión de la soberanía de un territorio, no podía aceptar la superioridad de ningún otro poder — salvo, evidentemente, el de la soberanía nacional-, y menos aún tratándose de tres jerarcas distintos, que podrían poner en riesgo la unidad del Estado. ${ }^{53}$ Sin embargo, desde esta perspectiva, el poder de los Estados de la primera mitad del siglo XIX, y particularmente de la primera república federal, era bastante débil. Como señalaron en su momento los ideólogos liberales de la época, en particular José María Luis Mora, las "fuerzas del progreso" que pugnaban por el establecimiento pleno del gobierno representativo encontraban ante sí la fuerza del "espíritu de cuerpo"; es decir, de las corporaciones, en particular las militares y eclesiásticas. ${ }^{54}$ Mas en este primer momento, ninguno de los nuevos estados optó por soluciones radicales, antes bien intentaron repetir la conjunción con la Iglesia que se daba a nivel nacional, siguiendo una solución común para la época: los estados obtenían lealtad para sí por medio de instancias intermedias tradicionales. ${ }^{55}$

En este contexto, Veracruz -al igual que San Luis Potosí o Guanajuato- se encontraba en una situación particularmente desventajosa

52 Decreto núm. 6 del Congreso Constituyente del Estado de Veracruz, "Rogaciones públicas implorando los auxilios del Todopoderoso para el acierto en las deliberaciones del congreso", 12 de mayo de 1824, en Blázquez Domínguez y Corzo Ramírez: Colección de Leyes... , tomo I, págs. 36-37.

$53 \mathrm{Al}$ contemplar la posibilidad de dictar leyes para cada porción del estado correspondiente a cada diócesis, los legisladores exclamaron: “¿Qué monstruosidad dentro de un mismo Estado!”. Copia de la exposición dirigida al Congreso de la Unión por el Congreso Constituyente del Estado de Veracruz el 19 de noviembre de 1824, AGN, Justicia Eclesiástica, 147, "Bula pontificia sobre la erección de una Mitra en el Departamento de Veracruz", f. 241v.

54 Véase Mora, José María Luis: "Revista política de las diversas administraciones que la República Mexicana ha tenido hasta 1837”, en Obras completas, Vol. 2, Obra política II, Secretaría de Educación Pública/Instituto de Investigaciones Dr. José María Luis Mora, México, 1996, págs. 369-409.

55 Cfr. Hobsbawm, Eric: Naciones y nacionalismo desde 1780, Crítica, Barcelona, 1991, pág. 91. 
por su incapacidad para establecer comunicación directa con el alto clero diocesano. Estados como Puebla podían solucionar sus roces con la autoridad eclesiástica a través de la negociación, aprovechando las relaciones de las élites con el alto clero, en particular en el caso de los legisladores - clérigos muchos de ellos- evitando la exhibición pública de la debilidad de la nueva soberanía. ${ }^{56}$ En cambio, los políticos veracruzanos, que por otra parte estaban también estrechamente vinculados a las corporaciones eclesiásticas locales, no contaban con vías de acceso a la sede episcopal, ${ }^{57}$ por lo que la creación de la vicaría general se presentaba como una alternativa para avanzar en la consolidación de su autoridad sin salir del marco establecido por el régimen. Cabe reconocer que ni siquiera alteraban el mapa eclesiástico mexicano y aceptaban que, aunque con facultades extensas, el vicario sería necesariamente una autoridad por debajo de la episcopal; además, como la intervención del Estado en la provisión de beneficios eclesiásticos se limitaba a la exclusiva, ni siquiera tendrían pleno control de su nombramiento.

Visto de esta manera, el intento de los legisladores no constituía sino un intento de fortalecer, al menos indirectamente, las lealtades de su nuevo entorno, y no tenía realmente gran originalidad. En otros estados los congresos y gobernadores se embarcaron en empresas similares. Jalisco, por ejemplo, garantizó la protección de la Iglesia, pero estableciendo al mismo tiempo que la gestión de las finanzas de la diócesis de Guadalajara quedaran bajo su salvaguarda. ${ }^{58}$ Era, pues, entendido por parte de las elites de cada estado que la Iglesia habría de insertarse, no ya tan sólo en el ámbito de lo nacional, sino también en lo local.

Resulta significativo que la representación veracruzana no causara contestación alguna del obispo poblano, ¿reconocía éste la legitimidad de la solicitud veracruzana? De momento no contamos con acceso a las fuentes que nos permitan saberlo. Por otra parte, los congresistas tampoco vieron cumplido su objetivo, toda vez que las negociaciones en Roma no pasa-

$56 C f r$. Tecuanhuey, Alicia: "Los miembros del clero en el diseño de las normas republicanas, Puebla, 1824-1825”, en Tecuanhuey Sandoval, Alicia (coord.): Clérigos, políticos y política. Las relaciones Iglesia-Estado en Puebla, siglos XIX y XX, Instituto de Ciencias Sociales y Humanidades de la Benemérita Universidad Autónoma de Puebla, Puebla, 2002, págs. 59-66.

57 Connaughton: "El ocaso del...”, pág. 252, afirma en ese sentido: "La relación eclesiástica con las regiones del país rebasaba los nexos íntimos entre los clérigos, los gobernantes y la sociedad dentro de las estructuras político-eclesiásticas establecidas".

58 Pérez Memen, Fernando: El Episcopado mexicano y la independencia de México, Jus, México, 1973, págs. 246-251. 
ron del tema de la provisión de los obispados vacantes. ${ }^{59}$ La solicitud habría de ser retomada, de forma notoriamente distinta, nueve años más tarde, en 1833, cuando un pronunciamiento permitiera el ascenso al poder de los liberales radicales.

\section{"Ideas ultramontanas" y pretensiones "justas e ilustradas"}

A principios de febrero de 1833, el III Congreso Constitucional veracruzano envió una copia de la exposición del Constituyente de 1824 sobre la creación de una vicaría general autónoma al deán poblano Miguel Ramos Arizpe, por entonces ministro de Justicia y Negocios Eclesiásticos, solicitando la intervención del presidente de la República a fin de que el proyecto de la vicaría llegara a concretarse, una vez que se reuniera el Congreso de la Unión, por entonces en proceso de instalarse. Para esas fechas, las posturas se habían radicalizado y existía ya una marcada tendencia entre los liberales en pro de un control más estrecho de la Iglesia por los Estados. Muestra de ello son las propuestas hechas unos años atrás, en abril de 1829, en el Congreso de la Unión y en los Congresos de México y Zacatecas ${ }^{60}$ tendientes a crear una diócesis en cada estado y a facultarlos para nombrar a los obispos respectivos, acaso solamente con la confirmación del arzobispo de México; ${ }^{61}$ el III Congreso veracruzano había funcionado por primera ocasión en 1829, y expresó opiniones similares.

En su carta que remitía la copia de la exposición, los legisladores veracruzanos denunciaron la relación del Estado con las tres Sillas Episcopales: "sin que ninguna de ellas se encuentre en su seno, ni le proporcione todos los alivios espirituales y temporales de su instituto, ni el esplendor que prestan las cuantiosas rentas que se estrahen de la riqueza de

59 Sobre las negociaciones de la primera república con la Sede Apostólica véase: Gómez Ciriza: México ante la diplomacia vaticana; Staples, Anne: La Iglesia en la primera república federal mexicana (1824-1835), Secretaría de Educación Pública (SepSetentas, 237), México, 1976, págs. 74-85.

60 Pérez Mémen: El Episcopado..., págs. 268-270. En aquel mes el propio Congreso de Veracruz había repetido por primera vez la exposición del Constituyente.

61 Las legislaturas de aquel año, ligadas a la masonería yorkina, actuaban inspiradas por ideólogos como Lorenzo de Zavala, acaso uno de los críticos más feroces de la Sede Apostólica en aquellos años, (véase Trejo, Evelia: "Los argumentos en discordia. Religión e Iglesia en la obra de Lorenzo de Zavala", en Matute, Álvaro, Evelia Trejo y Brian Connaughton (coords.): Iglesia, Estado y Sociedad en México. Siglo XIX, Grupo Editorial Miguel Ángel Porrúa/Facultad de Filosofía y Letras-Universidad Nacional Autónoma de México, México, 1995, págs. 211-216) y quien promoviera el nombramiento del también yorkino José María Alpuche e Infante para arzobispo de México. 
este pais". De ahí, decían, "y de la funesta influencia que egercen todavía las ideas ultramontanas", se derivaba la oposición de los obispos a las reformas del Constituyente; reformas que iban "de acuerdo con los mejores criminalistas", "dictados con mas sabiduria y verdadero espiritu de religión". ${ }^{62} \mathrm{Tal}$, pues la insistente protesta de los legisladores ante el atrevimiento de los jerarcas eclesiásticos a cuestionar las "sabias" decisiones de la representación soberana. Era un punto sobre el que ya los constituyentes se habían inconformado, pero que habían atribuido a las distancias y pareceres personales; ${ }^{63}$ ahora, en cambio, los legisladores lo trataban directamente en términos ideológicos. Puede decirse que esa reiterada descalificación de los prelados procedía de una visión más clara a favor de la consolidación del poder del Estado, y es que el nuevo régimen liberal impedía aquellas representaciones, como las de 1824 y 1825, a que los obispos estaban habituados durante el Antiguo Régimen, pues como señaló Bartolomé Clavero para el caso español a partir del cambio político, "no hubo posibilidad de resistencia ni por jurisprudencia ni por justicia ninguna ante estos actos de poder de unas leyes, frente al poder de las mismas". ${ }^{64}$

La carta concluía en una advertencia:

“... ha asomado ya el proyecto de separarse absolutamente de las mitras de Megico, Puebla y Oajaca (sic), y si hubiera llegado á ponerse en accion, tal vez habrian nacido otras pretensiones mas abanzadas, (sic) que aunque no menos justas é ilustradas, aumentasen los elementos de discordia y produgesen una escision de incalculable trascendencia y funesta para toda la republica."

Y no obstante de los calificativos favorables a las ideas avanzadas, de nuevo podemos afirmar que el Congreso se mantuvo dentro de los límites marcados por los pactos entre la Iglesia y el Estado: a pesar de la contundencia de sus argumentos, se limitaron a insistir en el tema de la vicaría general autónoma, y al final de su carta aseguraron al ministro que su "prudencia" y convencimiento del empleo de "medios suaves" había detenido

62 Carta de los Secretarios del Congreso del Estado Libre y Soberano de Veracruz al Secretario de Justicia y Negocios Eclesiásticos, Veracruz, 9 de febrero de 1833, AGN, Justicia Eclesiástica, 147, "Bula pontificia sobre la erección de una Mitra en el Departamento de Veracruz", f. 239v.

63 El Congreso Constituyente había escrito: “...tres prelados que gozan de distinta gerarquia, que gozan de distintas rentas ... y que cada uno tiene un clero educado según las costumbres de su respectivo Pais, no pueden siempre pensar del mismo modo". Copia de la exposición dirigida al Congreso de la Unión por el Congreso Constituyente del Estado de Veracruz el 19 de noviembre de 1824, AGN, Justicia Eclesiástica, 147, "Bula pontificia sobre la erección de una Mitra en el Departamento de Veracruz", f. $241 \mathrm{v}$.

64 Clavero: “El cambio político...”, pág. 134. 
el avance de "pretensiones mas avanzadas", ${ }^{65}$ en los períodos previos en que funcionó esa legislatura tampoco hubo medidas radicales, de hecho, al iniciar sus primeras sesiones, en febrero de 1829, dispuso celebrar "con asistencia de las autoridades en todas las parroquias del estado, una misa solemne con sus respectivas preces, en acción de gracias al Todopoderoso por la feliz instalación del Honorable Congreso, é implorando la asistencia del Espíritu Santo en sus deliberaciones", ${ }^{66}$ contrario a los estados que comenzaron a apropiarse de los diezmos, formando juntas especiales para su administración, independientes de los Cabildos de las Catedrales, el Consejo de Gobierno veracruzano se limitó a demandar su participación en las rentas de la vacante episcopal a la muerte del obispo de Puebla Antonio Joaquín Pérez. ${ }^{67}$

Mas resulta significativo que también de entonces, del 11 de abril de 1829 , procede la única circular que se conserva en que el gobierno veracruzano intentó normar la conducta de los curas párrocos comprendidos en su territorio. En ella, el gobernador Antonio López de Santa Anna reprochaba a los sacerdotes, el "mezclar en sus pláticas o sermones, materias políticas..." y además que siendo ellos "Ministros de Paz", "no sólo sirven de instrumentos para alterarla ... sino que con su influjo desde la cátedra del Espíritu Santo han llegado á trastornar el orden público..." ${ }^{68}$ Un claro ejemplo de lo que, según hemos venido argumentando, los políticos radicales de ese momento esperaban del clero en general: que garantizara la lealtad de los pueblos al régimen, en aras, como escribía el mismo Gobernador, del "buen servicio de Dios y el de la Nación".

\section{Un soberano en ejercicio de su libertad}

Apenas se instaló el IV Congreso Constitucional veracruzano (febrero de 1833), se nombró una comisión especial para discutir la posibilidad

65 Carta de los Secretarios del Congreso del Estado Libre y Soberano de Veracruz al Secretario de Justicia y Negocios Eclesiásticos, Veracruz, 9 de febrero de 1833, AGN, Justicia Eclesiástica, 147, "Bula pontificia sobre la erección de una Mitra en el Departamento de Veracruz", fs. 239-243.

66 Decreto no. 152 de la III Legislatura Constitucional del Estado de Veracruz del 24 de febrero de 1829, en Blázquez Domínguez y Corzo Ramírez: Colección de Leyes..., tomo II, pág. 114.

67 Decreto s/n del Consejo de Gobierno del Estado de Veracruz,15 de mayo de 1829 en Blázquez Domínguez y Corzo Ramírez: Colección de Leyes..., tomo II, págs. 137-138. Sobre lo sucedido en otros Estados véase: Staples: La Iglesia..., págs. 106-114 y Pérez Mémen: El Episcopado..., págs. 253-257.

68 Circular del Gobierno Supremo del Estado Libre y Soberano de Veracruz, 11 de abril de 1829, en Blázquez Domínguez y Corzo Ramírez: Colección de Leyes..., tomo I, págs. 119-120. 
de establecer una diócesis en el estado, el dictamen resultante se publicó en el periódico Aurora de la libertad de la ciudad de Puebla el 10 de abril de 1833.

Los integrantes de la comisión reiteraron la necesidad de una autoridad eclesiástica en el estado al nivel de la civil, a partir de considerandos similares a los hechos desde 1824: "las necesidades espirituales de los pueblos" la complejidad de la relación con las tres mitras, y sobre todo "el mas inminente peligro de turbarse la armonia". La primera innovación fue que para los congresistas tal autoridad debía ser un obispo y ya no un icario, ${ }^{69}$ pues este último sería una innovación "demasiado peligrosa", que podría "rozarse con el cisma" en virtud de la falta de delimitación de sus facultades. En consecuencia, dictaminaron a favor de la creación de un Obispado con los mismos límites del estado, siguiendo — por parafrasear su argumento- el ejemplo de los soberanos católicos antiguos.

Como justificación, los legisladores presentaron una situación dramática en la atención pastoral del Estado: los obispos ignoraban "hasta el genio y costumbres del pueblo que rigen", no había visitas episcopales, ${ }^{70} \mathrm{ni}$ sínodos diocesanos. Como si Puebla, México y Oaxaca fuesen ciudades extranjeras, decían que "los ciudadanos del estado tienen que salir de su territorio en todos los asuntos del resorte eclesiástico y trasladarse a un país de diversas leyes y costumbres, donde no cuentan con los recursos y relaciones que en el suyo, ni con el apoyo de sus autoridades". El diezmo causaba perjuicios a la agricultura sin reportar beneficios, pues no había establecimientos educativos eclesiásticos. En suma, "el unico remedio a tanto mal, es la creación de un obispado tal como lo consulta la comision". ${ }^{71}$

La postulación del nuevo obispo la haría el Estado, consultando a los curas párrocos del territorio, dejando su presentación ante la sede apostólica al gobierno federal. El obispado sería confirmado por el Papa, no por su legitimidad, sino porque: “... es preciso confesar que la práctica de los siglos posteriores hasta nuestros dias ha reservado a Roma la facultad de

69 Solicitando un Obispo, reclamaban un jerarca con plena potestad, pues el Vicario general proyectado desde 1825, habría tenido sólo potestades delegadas-vicariales- de los tres obispos.

70 Visitas episcopales, sin embargo, las hubo al menos hasta la época del obispo Manuel Ignacio González del Campillo, que recorrió la región central de Veracruz hacia 1808 según se dio cuenta en "Caminos públicos y de comunicación", Gazeta de México, miércoles 2 de marzo de 1808, pág. 156, la guerra civil posterior seguramente había impedido regularizarlas.

71 "Dictamen presentado al Honorable Congreso por la comisión especial que entiende en el negocio del establecimiento de un Obispo en el Estado", Aurora de la Libertad, miércoles 10 de abril de 1833 , págs. $2-3$. 
confirmar y autorizar con sus bulas esta clase de nombramientos. La posesion por lo menos le da un derecho...". La prevención iba ligada además a sus preocupaciones por el orden público, toda vez que reconocían que "No habría peor azote para el país que las disensiones religiosas, y estas serian seguras si se rompiese el vínculo de la unidad católica". ${ }^{2}$

El obispo así nombrado sería, desde luego, dotado por el Estado con una "cantidad moderada", de acuerdo con las posibilidades presupuestarias, permitiendo así suprimir los diezmos, cuya recaudación calificaron los legisladores: "en lo economico, un impedimento a las mejoras del estado, en lo politico un establecimiento monstruosos, en lo moral, una causa de corrupción, y en lo religioso una cosa agena ya de su objeto primitivo". ${ }^{73} \mathrm{El}$ obispado, finalmente, habría de requerir la ratificación del Congreso General.

Contrario a lo hecho en 1824, en el dictamen se aprecia claramente la voluntad de los congresistas de afirmar, sin mayores concesiones, su posición de representantes de la soberanía estatal. Fue en una discusión sostenida varios meses más tarde, a propósito de la supresión de los conventos, cuando el senador José Nicolás Esteves mostró de manera mucho más explícita y contundente esta idea respecto de los derechos del Estado en materias eclesiásticas. Esteves afirmó: "El Congreso de Veracruz es también un soberano que está en el egercicio (sic) de su libertad". ${ }^{74}$

Los legisladores justificaron su postura aludiendo a la concordancia de su proyecto con las costumbres antiguas de la Iglesia, mas resultaba claro que su proposición iba más bien relacionada con los planteamientos de algunos de los ideólogos liberales del momento, particularmente del doctor José María Luis Mora, y de su Ensayo sobre los bienes eclesiásticos, citado también por los legisladores en la discusión sobre la supresión de los conventos, y quien había expuesto con amplitud la idea de que la Iglesia presentaba dos naturalezas, una religiosa y otra civil; esta última considerada completamente bajo la autoridad del gobierno de la república a través del Patronato Nacional, heredero del antiguo Patronato Regio. Sin afirmarlo

72 Aurora de la Libertad, año 1, núm. 101, miércoles 10 de abril de 1833, pág. 3, "Dictamen presentado al Honorable Congreso por la comisión especial que entiende en el negocio del establecimiento de un Obispo en el Estado".

73 Aurora de la Libertad, año 1, núm. 101, miércoles 10 de abril de 1833, pág. 4, "Dictamen presentado al Honorable Congreso por la comisión especial que entiende en el negocio del establecimiento de un Obispo en el Estado".

74 Sesión del H. Congreso de Veracruz, en que se discutió y aprobó el Decreto que declara de la pertenencia del Estado algunos Conventos y sus propiedades, 1833, pág. 10. 
explícitamente, los legisladores veracruzanos lo entendían así, y de manera radical, pues el dictamen se arrogaba los dos derechos más importantes comprendidos en las discusiones de la época: la creación de una diócesis y el nombramiento de los obispos. ${ }^{75} \mathrm{La}$ "postulación", radicalmente distinta de la mera exclusiva concedida en 1822 por los representantes diocesanos y extendida a los estados entre 1829 y 1830 , era una facultad arrebatada a los Cabildos Catedrales -institución que no se contempló en el caso veracruzano - , que eran los que debían formar las listas de los candidatos a obispos; el gobierno federal tampoco tendría mayor intervención, más que el mero trámite de comunicar a Roma el expediente del postulado.

El decreto fue aprobado por las cámaras reunidas el 22 de marzo de 1833 y publicado en la misma fecha, prácticamente sin cambios respecto del dictamen, ${ }^{76}$ mas no llegó a entrar en vigor pues el Congreso General no alcanzó a ratificarlo, y quedó nuevamente suspendido el expediente de la creación del obispado de Veracruz.

La conducta de los congresistas de 1833 cae, sin duda, en los marcos de la política moderna. Como en los casos anteriores, puede leerse aquí un esfuerzo por construir lealtades para una entidad política bastante reciente todavía, y en algunos lugares cuestionada por ciertas corporaciones religiosas. ${ }^{77}$ La diferencia estriba acaso en la imposición de la nueva autoridad por encima del pacto mismo que había hecho posible su existencia, pues se ponía en cuestión simultáneamente las atribuciones de la federación en materia eclesiástica y el respeto a la Iglesia que, según hemos visto, había asentado su postura en la supresión del patronato desde 1822.

\section{Y llega el obispado}

A poco más de una década del decreto 18 de la Legislatura de Veracruz, reapareció la propuesta de creación del obispado, en esta ocasión en el Ministerio de Justicia y Negocios Eclesiásticos. De manera un tanto inesperada, y gracias a la intervención de dos xalapeños: D. Antonio María

75 Ambos puntos estaban históricamente ligados con el patronato, toda vez que eran los derechos específicos que el Papa Julio II concedió a los Reyes Católicos en 1508 en la bula Universalis Ecclesiae, la bula sobre la que se legitimaba el patronato.

76 Decreto no. 18 de la IV Legislatura Constitucional del Estado de Veracruz, Veracruz, 18 de marzo de 1833 en AGN, Gobernación, 66, 2.

77 Nos referimos específicamente al caso de Orizaba, en que el jefe político solía tener problemas para garantizar la paz pública frente a la influencia de los eclesiásticos. 
de Rivera, uno de los "hombres de bien" de la época, y el Gral. Antonio López de Santa Anna, presidente de la República, ${ }^{78}$ el ministerio instruyó, ya sin mayor consulta, al enviado mexicano ante la sede apostólica, José María Montoya, para que solicitase la creación de la nueva Silla Episcopal en una nota de 28 de noviembre de 1843. Las gestiones de Montoya fueron sumamente eficaces: luego de diversas comunicaciones con el secretario de Estado, cardenal Lambruschini, el 18 de enero de 1845 remitió al Ministerio la bula Quod Olim Propheta, fechada el 5 de enero de 1844, por la que se erigía, finalmente, la nueva diócesis. ${ }^{79}$

Para entonces, México era una república centralista regida por las Bases orgánicas de la República Mexicana, que establecían que los rescriptos pontificios, antes de su ejecución, debían recibir el pase del presidente de la República con acuerdo de su Consejo de Gobierno. ${ }^{80}$ Por ello, el 12 de abril de 1845, el ministro Riva Palacio pasó la bula al Consejo, éste lo revisó en su comisión eclesiástica, encabezada por el Dr. Juan Manuel Irisarri, arzobispo de Cesárea, quien, acaso sorprendido por el documento que se le remitía, solicitó de inmediato se le enviase el expediente al respecto, luego los informes de los obispos involucrados, y por último, el del gobierno y la asamblea del entonces departamento de Veracruz, requerido por orden del ministerio del 3 de junio. ${ }^{81}$ Los representantes departamentales habrían de reiterar su interés en la erección de la mitra, ciertamente ya no con la misma fuerza que lo había hecho el congreso estatal, aunque sí con argumentos que en realidad no eran muy distintos de los empleados en su momento por sus antecesores.

El 26 de enero de 1846 el gobernador veracruzano transcribió al Ministerio de Justicia y Negocios Eclesiásticos la resolución de la asamblea departamental. La asamblea había formado una comisión para tratar el asunto y responder puntualmente la orden del ministerio; su dictamen, aprobado sin cambios, resumía primero los antecedentes de la solicitud y sus trámites, únicamente en los años previos a la independencia: nada se decía de las representaciones enviadas por los congresos estatales. Hecho lo anterior, se limitaron a contestar afirmativamente las preguntas plantea-

78 La correspondencia sobre este punto puede consultarse en Barradas, Celestino: Historia de la Iglesia en Veracruz, Ediciones San José, Xalapa, s.f., tomo I, págs. 127-132. $135-144$.

79 El texto de la bula en castellano puede verse en Barradas: Historia de la..., tomo I, págs.

80 Bases orgánicas de la República Mexicana, artículo 87, fracción XIX.

81 AGN, Justicia Eclesiástica, 147, "Bula pontificia sobre la erección de una Mitra en el Departamento de Veracruz", fs. 246-268v y 317-330. 
das por el ministerio sobre si habría edificios convenientes para el obispo, su cabildo y el seminario diocesano, y si las rentas decimales bastarían para sustentar tales instituciones con un mínimo de 15 mil pesos, sólo incluyeron dos puntos al final de su dictamen: uno que recordaba la "absoluta necesidad" y "positiva utilidad" de erigir la nueva diócesis, y el segundo, más significativo, que reiteraba que en su delimitación "debe comprenderse todo el territorio q.e se incluye en los limites civiles de q.e hoy consta este Dept.o ó en adelante constare". ${ }^{82}$ El obispado se revelaba así como una forma de reforzar una delimitación territorial de carácter político, y por ello mismo, como una institución que habría de garantizar la lealtad de los habitantes, y en particular la de los clérigos.

En los meses siguientes el gobernador veracruzano se ocupó de recordar la urgencia de que la bula tuviese cumplimiento, primero con una breve nota del 22 de marzo de 1846 fundada en "las necesidades espirituales de los pueblos"; ${ }^{83}$ después, el 8 de mayo, fue más allá y, además de un punto ya conocido — la falta de visitas pastorales—, agregó uno más: según él, la provisión de curatos se hacía "las más veces" interinamente, y el cura así nombrado "solo se afana pr. reunir cuanto pueda pa. sostenerse en caso de ser removido", surgían por ello conflictos con sus feligreses en los que la autoridad civil intervenía, "siguiendose disgustos y aun escándalos q.e acaban algunas veces con sucesos muy desagradables" hasta que las quejas llegaban finalmente a la Silla Episcopal, la que no alcanzaba a solucionar el conflicto. "No será lo mismo — concluía — cuando el Dep.to tenga en su seno su silla episcopal q.e palpe de cerca todos los abusos q.e se cometen y que en contacto inmediato con las superiores autoridades obrará segun lo exija la justicia y conveniencia de cada poblacion". ${ }^{84}$ Cabe señalar que el funcionario no citaba ningún caso particular del tipo de conflicto que describía y, por otra parte, tampoco ocultaba que a través de la provisión interina la mitra evitaba el derecho de exclusiva que correspondía al gobierno departamental. La urgencia del gobierno pues, parece más una preocupa-

82 AGN, Justicia Eclesiástica, 147, "Bula pontificia sobre la erección de una Mitra en el Departamento de Veracruz", fs. 250-253v, Becerra al Presidente del Consejo de Gobierno, México, 5 de febrero de 1846 .

83 AGN, Justicia Eclesiástica, 147, "Bula pontificia sobre la erección de una Mitra en el Departamento de Veracruz", fs. 256-256v, Becerra al Presidente del Consejo de Gobierno, México, 28 de marzo de 1846

84 AGN, Justicia Eclesiástica, 147, "Bula pontificia sobre la erección de una Mitra en el Departamento de Veracruz”, fs. 263-264v, Becerra al Presidente del Consejo de Gobierno, México, 20 de mayo de 1846 . 
ción política, interesada en reforzar su legitimidad, que propiamente un interés pastoral.

Aunque el Consejo de Gobierno recibió estas notas, su caída a mediados del año y el inicio de la guerra contra los Estados Unidos retrasaron nuevamente el trámite de la bula; éste se reanudaría hasta 1848, cuando se desarrollara el conocido debate entre las principales ciudades del estado que solicitaban ser beneficiadas con la sede diocesana.

\section{Comentarios finales}

"Utilidad, necesidad y consentimiento de los Obispos interesados" habían sido, como indicamos antes, los criterios para la erección de nuevas diócesis en la monarquía hispánica. Veracruz insistió en la utilidad y necesidad, mas no consiguió la aprobación episcopal, que probó seguir siendo un argumento con un peso específico tal que no pudo ser compensado con el apoyo del virrey. En ese sentido, este caso ejemplifica los límites de los cambios y reformas promovidas por los monarcas borbónicos; a pesar del fortalecimiento de la autoridad secular frente al clero, parece claro que en este tipo de negocios, menos llamativos, pero acaso más cercanos a las élites locales del virreinato, la Corte no podía sino respetar los equilibrios tradicionales entre las dos potestades.

Un cambio drástico ocurre entre uno y otro período, la coyuntura de la independencia ciertamente no modificó la confesionalidad del Estado y el respeto a las autoridades religiosas, pero el contexto institucional ya no es el mismo, existe la posibilidad, que se hará realidad al final de la primera república, y sobre todo a mediados de siglo, de medidas unilaterales de parte del gobierno civil que es ya, como hemos dicho, la representación de un Estado en el sentido moderno del término, un Estado que además requería ganar lealtades.

Desde esa óptica, los congresistas veracruzanos llevaban razón en elegir un obispo y no un vicario de tres obispos distintos: sin duda, habría también garantizado un acceso directo a los curas párrocos y a los frailes de todo el territorio estatal, quienes desde el púlpito y el confesionario eran los que realmente tenían contacto directo con sus comitentes. Sin embargo, irónicamente en esta época los jerarcas eclesiásticos tampoco se sentían plenamente seguros de la lealtad ni de los fieles ni de los sacerdotes a su cargo; al respecto, el obispo Antonio Joaquín Pérez reconoció: 
“... soy de parecer que hasta tanto no estemos constituidos y cimentado en todas partes el sistema federal que hemos jurado están como enervadas las autoridades y principalmente la eclesiástica, lo diré con dolor, para hacerse obedecer y acatar de los pueblos...". ${ }^{85}$

Por el contrario, intentos menos explícitos de controlar a la Iglesia acaso fueron más efectivos en asegurar la lealtad de la jerarquía, como lo muestran tanto los primeros años del primer federalismo como la década de centralismo, período este último en que el gobierno federal se sostuvo en buena medida gracias a los préstamos del Episcopado. ${ }^{86}$ En cambio, para ir construyendo la lealtad de la sociedad fueron empleándose otros medios conforme avanzaba el siglo, como la creación de un calendario cívico secularizado, enriquecido, en parte gracias a los caudillos militares $;{ }^{87} \mathrm{o}$ bien, la movilización de otras identidades particularistas locales, propias de otros actores con no menos presencia social, como los hacendados y rancheros.

Entre tanto, la historia de la diócesis veracruzana conocería diversas vicisitudes, que involucraban sobre todo a las ciudades de Xalapa, Orizaba y Veracruz, que se disputaron la Silla Episcopal, hasta concretarse la resolución final a favor de la primera ciudad en 1850. Todavía pasarían trece años para que se preconizara al primer obispo, D. Francisco Suárez Peredo y Bezares, en 1863. Para entonces la postura de los liberales mexicanos iba ya en el sentido de separar la Iglesia del Estado, y dejar en el olvido el tema del control del Estado sobre la Iglesia, propio de la antigua querella del Patronato Nacional.

85 Citado por Connaughton, Brian: Ideología y Sociedad en Guadalajara, Consejo Nacional para la Cultura y las Artes, 1992, pág. 252. Sobre los problemas locales de los curas párrocos y sus feligreses en los primeros años de la década de 1820: Rangel Silva, José Alfredo: "Lo que antes era Casa de Dios... Adaptaciones del liberalismo en los ámbitos locales, 1820-1825", Historia Mexicana, vol. LIII, núm. 1, México, 2003.

86 Véase Connaughton: "El ocaso del proyecto...".

87 Lempérière: “¿Nación Moderna...?”, págs. 167-174. 